Article

\title{
Carbonate Neoformations on Modern Buildings and Engineering Structures in Tyumen City, Russia: Structural Features and Development Factors
}

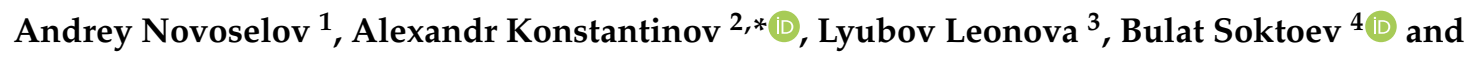 \\ Sergey Morgalev ${ }^{5}$ \\ 1 Institute of Earth Sciences, University of Tyumen, Osipenko St. 2, 625002 Tyumen, Russia; \\ mr.andreygeo@mail.ru \\ 2 Oil and Gas Geology Research and Educational Center, Tyumen Industrial University, Volodarskogo St. 56, \\ 625000 Tyumen, Russia \\ 3 Laboratory of Regional Geology and Geotectonics, The Zavaritsky Institute of Geology and Geochemistry of \\ the Ural Branch (UB) of the Russian Academy of Sciences (RAS), Akademika Vonsovskogo St. 15, \\ 620016 Ekaterinburg, Russia; lvleonova@yandex.ru \\ 4 School of Earth Sciences and Engineering, National Research Tomsk Polytechnic University, \\ Lenina Ave. 2 bldg 5, 634028 Tomsk, Russia; bulatsoktoev@gmail.com \\ 5 Centre for Collective Use “Biotest-Nano", National Research Tomsk State University, Lenina Ave. 36, \\ 634050 Tomsk, Russia; 3030@sibmail.com \\ * Correspondence: konstantinov.alexandr72@gmail.com; Tel.: +7-982-782-3753
}

Received: 20 February 2019; Accepted: 12 March 2019; Published: 14 March 2019

\begin{abstract}
The paper presents the results of studying the development of calcite neoformations on the surfaces of modern buildings within the city of Tyumen. The objects of the study were carbonate crusts and stalactite-like bodies formed on the surfaces of five representative buildings in the city center. Research methods included visual diagnostics, optical microscopy, scanning electron microscopy with energy dispersive $\mathrm{X}$-ray spectroscopy, confocal laser scanning microscopy and semi-quantitative determination of the mineral composition by $\mathrm{X}$-ray diffraction analysis. The results of the study show that calcite is the main component of all carbonate crusts, while other minerals were found in small quantities. The microscopic studies revealed the differences in morphology of crusts developing on horizontal and vertical surfaces. The mycelium of fungi (presumably of the Penicillium group), represented by filamentous and often hollow hyphae covered with calcite, as well as relics of bacterial colonies were found in all studied samples. It was noted that the mycelium forms the structural frame of carbonate crusts and stalactites. Studies have shown that the prokaryotic-eukaryotic communities are responsible for the high rate of the urban speleothem growth and play the main role in calcite precipitation at the initial stages of their development.
\end{abstract}

Keywords: calcite; urban speleothems; biomineralization; fungi; crusts

\section{Introduction}

Building materials are subjected to a wide range of physical and chemical weathering processes in the urban environment. Significant temperature drops inside and outside buildings and frequent excessive moistening during hindered evaporation lead to gradual destruction of the initial structure and changes in the properties of natural construction materials [1-4]. The leaching of carbonate cement is one of the most common, notable, and potentially dangerous processes [5,6]. The dissolution of mineral compounds and their subsequent deposition leads to the deterioration of the bonding properties of the cement stone and the weakening of the entire engineering structure $[7,8]$. 
The development of carbonate crusts, fades, sinters, and sometimes, stalactite-like forms on the facades of buildings is an important indicator of this process $[7,9,10]$. Neoformations on the surfaces of facing materials also significantly degrade the aesthetic appeal of the urban architecture; worsen the preservation of the monuments of architectural and historical heritage; and demand expensive measures for their removal [11-14]. In addition, the weathering of building materials in the conditions of an urbanized area is intensified due to the impacts of corrosive chemical compounds occurring in the compositions of atmospheric aerosols, snowmelt, and rainfall waters $[15,16]$.

In Russian scientific tradition, the formation of carbonate crusts, sinters, and stalactites within buildings and engineering structures is observed as "technogenic speleogenesis", and such manifestations are called "technogenic speleotherms" or "urban speleotherms" [17,18]. It is generally accepted that the development of these formations is similar to those that take place in karst cavities. These processes are considered to be predominantly chemogenic but proceed much more quickly [19]. Development of technogenic speleothems has been frequently reported for various manmade constructions operating under conditions of excessive moistening: technological cavities, sewage, ventilation and water purification systems, dam patterns, concrete slabs of bridges, basements of old buildings, walls, mine workings, tunnels, fortifications, etc. [20-24]. It should be noted that, despite the significant spread of this phenomenon, the mechanisms of technogenic speleothem development have been studied much less than their natural analogs. The problems with the possible rates and conditions of their formation are still debatable. There is no consensus on the roles of microbial communities and other living organisms in the formation of calcite speleotherms, since it is difficult to explain high growth rates only from the standpoint of chemogenic mineralization [19].

The formation of the majority of technogenic speleothems described in the scientific literature occurs in enclosed, poorly ventilated spaces of old engineering constructions and on architectural monuments [18]. This work presents the results of studying technogenic calcite neoformations (carbonate crusts and stalactites) developing within the high levels of the Tura River embankment and several other buildings in the central part of Tyumen city. These localities are not typical for urban speleotherms due to the high degree of airflow and the relatively short age of the constructions under consideration. The development of calcite crusts, sinters, and stalactites under such conditions is of interest, as they can serve as potential indicators of the intensity of the leaching processes and the destruction of natural building materials, such as cement stone. Moreover, they could be of importance for attaining a better understanding of the possible rates and formation mechanisms of authigenic minerals in urban environments.

This work aims to reveal the features of the mineral composition, structure, and possible mechanisms of the formation of carbonate crusts and stalactites on the facades of recent buildings and engineering structures in the city of Tyumen, as well as identifying the factors that contribute to this phenomenon.

\section{Materials and Methods}

\subsection{Study Objects}

The city of Tyumen is located in the south of Western Siberia on the high terraces of the Tura River (Figure 1). The left bank of the river is low-lying and marshy; the right bank, where the business and historical center of Tyumen is located, is rather steep and is composed of Late Quaternary lacustrine-alluvial loams and, to a lesser extent, sands. The climate is moderately continental; the average precipitation is $480 \mathrm{~mm}$ with a maximum in summer. The average temperature in January is $-15^{\circ} \mathrm{C}$, and in July is $18.8^{\circ} \mathrm{C}$; the average annual air temperature over a long period is $0.7^{\circ} \mathrm{C}$. The relative air humidity is $75 \%$, varying by month from $59 \%$ to $83 \%$. The highest values fall in the colder months, and the lowest values fall in the spring months [25]. 

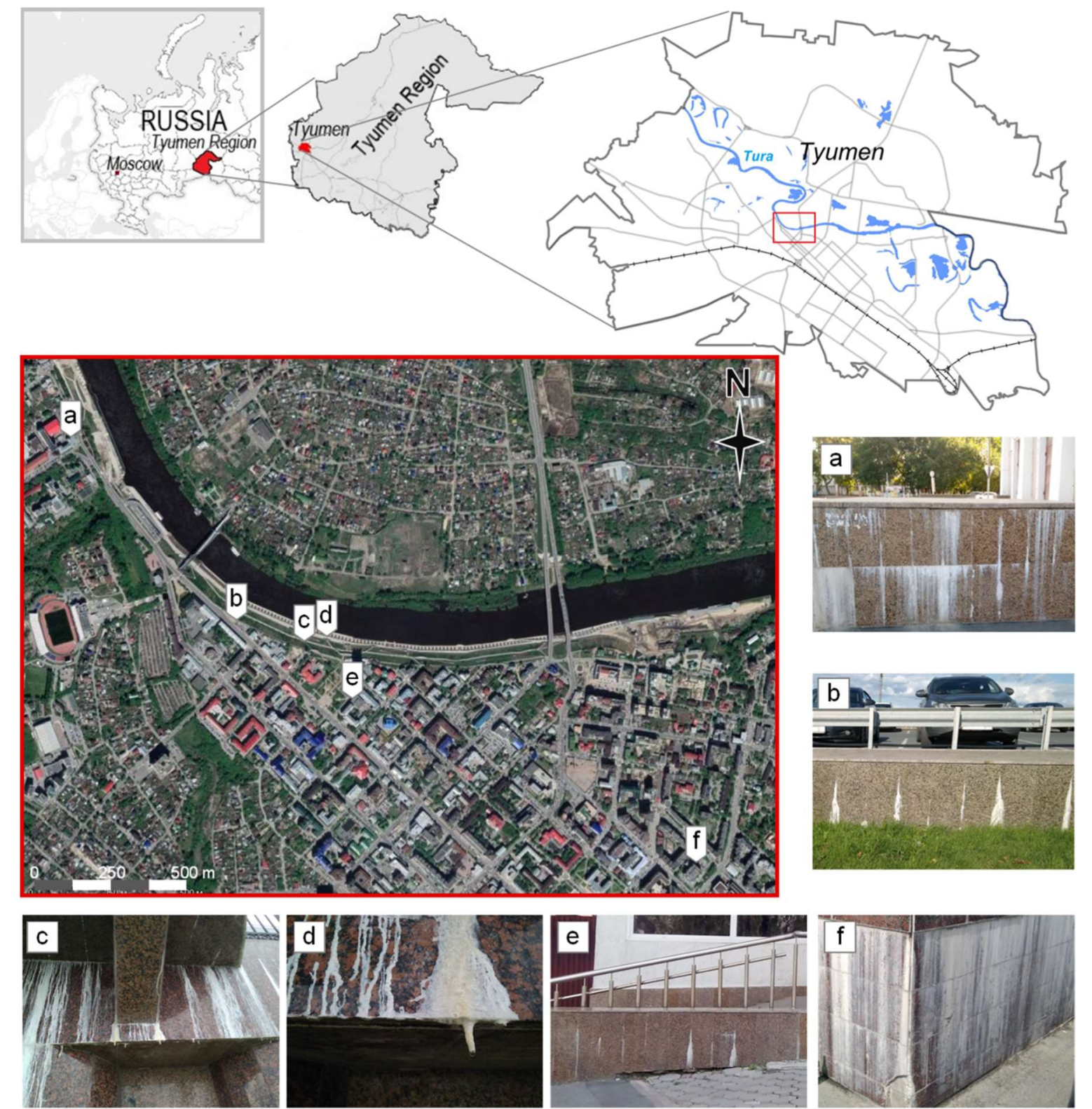

Figure 1. Location of the objects of study and photographs of carbonate neoformations on the facades of buildings and engineering structures of Tyumen: (a) crusts on the porch of the building of the Tyumen Industrial University; (b) crusts on the upper level of the Tura River embankment; (c) crusts on the lower levels of the Tura River embankment; (d) stalactite-like bodies of the second and third levels of the embankment; (e) crusts on the facades of the restaurant "Na Tsarskoi"; and (f) crusts on the facades of the Department of Mineral Resources and Ecology of the Tyumen Region.

The history of Tyumen dates back more than 400 years. Up to the second half of the 20th century, the city developed as a relatively small commercial and transport center with predominantly wooden architecture. The intensive development of the West Siberian oil and gas fields led to fast growth of the city in the late Soviet period [26]. The formation of the modern architectural appearance of the city belongs to this period. The major source of air pollution is road transport, while large industrial enterprises have no significant impact, since they are located outside the city limits.

Five buildings from the Tyumen city center where carbonate crusts were diagnosed were selected as objects of research (Figure 1). The embankment of the Tura is one of the largest architectural projects in the history of the city. The supposed length of the entire construction is about $4 \mathrm{~km}$; the number of levels is 4 (the lower one is flooded in the springtime); and the average height is $25 \mathrm{~m}$. The first stage 
of the embankment (2.4 km long) from the Holy Trinity Monastery to the House of Merchant Prasolov was put into operation in 2012. Nowadays, construction works are ongoing at the sites of the second and third stages of construction from the bridge on Chelyuskintsev street to Maslovsky Vzvoz and from the Bridge of Lovers to the Babarynka River mouth. Most of the embankment is covered with massive granite slabs. The study objects are located within both the lowest and highest levels of the embankment, where manifestations of authigenic carbonate formation were found. The building of the Department of Mineral Resources and Ecology of the Tyumen Region (brought into operation in 2008), the building of the "Na Tsarskoi" restaurant (brought into operation in 1964; later, the facade was repeatedly rebuilt in the early 2000s), and the building of the Architectural Institute of the Tyumen Industrial University (commissioned in 1914; the facade was rebuilt in the early 2000s) are among the other objects of study. All the constructions under consideration are characterized by the presence of carbonate neoformations on their facades and visible traces of the destruction of facing materials.

\subsection{Analytical Methods}

Samples of carbonate crusts and stalactite-like neoformations as well as the cement stone were collected for microscopic and laboratory research within several sites of the fourth level of the Tura River embankment as well as from the facades of the above-mentioned buildings. In addition, the distribution and rate of the formation processes of carbonate crusts, sinters, and stalactites were visually examined, and annual and seasonal photo fixation of the changes were performed. In total, 22 samples of calcite neoformations (ten representing embankment and three for other locations), as well as 3 samples of cement stone from Tura River embankment, were collected for further analytical studies. All samples were examined in thin sections using polarizing microscope, while undisturbed samples using scanning electron microscopy. Selected samples of calcite neoformations and cement stone were selected for X-ray diffraction analysis. Crusts and stalactite-like bodies from Tura River Embankment were studied using confocal laser-scanning microscopy.

The most representative samples were dried at $60^{\circ} \mathrm{C}$ and used for further mineralogical and microscopic studies. The primary diagnostics of collected samples was carried out using a Leica EZ4 D stereomicroscope (Leica Microsystems, Wetzlar, Germany) with an integrated digital camera. The subsequent studies of representative samples were performed in thin sections made from selected neoformations (longitudinal and transverse sections) using an Eclipse LV100POL polarization microscope (Nikon, Tokyo, Japan) and an Axio Vert reflected light microscope (Carl Zeiss, Oberkochen, Germany). In addition, the undisturbed samples were studied using a TM3000 (Hitachi, Tokyo, Japan) scanning electron microscope with a Quantax 70 EDS attachment at $\times 100-5000$ magnification and a scanning electron microscope JSM-6390LV (Jeol, Tokyo, Japan) with an energy dispersing attachment (INCA Energy 450 X-Max 80). SEM observation were made under high vacuum (HV-mode) and mainly in the elemental composition mode (BSE, registration of back scattered electrons). While performing the EDS analysis, the voltage was 15 and $20 \mathrm{kV}$ for first and second devices, respectively.

The confocal microscopy has been successfully used to record traces of activity of living organisms [27] and to study the concentric structure of cave speleothems [28]. Therefore, selected samples of carbonate crusts were examined using a LSM 780 NLO confocal laser-scanning microscope (Carl Zeiss, Germany). Studies were performed on thin sections. Fluorescence excitation sources were 405 and $488 \mathrm{~nm}$ lasers. Images of urban speleothem fluorescence were made using an emission filter that recorded light in the wavelength range 505-539 $\mathrm{nm}$ (corresponding to the visible green range).

Semi-quantitative determination of the mineral composition was carried out using X-ray diffraction analysis on a DRON-2 X-ray powder diffractometer (Burevestnik, Russia) in the $2 \theta$ range of 3-40 . The diffractograms were processed using GeoQuant software to delete automatic recognition errors. Individual neoformations developed on the river embankment were also studied on a D2 Phaser X-ray diffractometer (Bruker, Hamburg, Germany) with $\mathrm{CuK} \alpha$ radiation in the $2 \theta$ range of $20-100^{\circ}$. 


\section{Results}

\subsection{Visual Examination}

Carbonate crusts and small drop-shaped stalactite-like bodies (Figure 1c,d) represent urban speleothems of the Tura embankment. At the lower level of the embankment, calcite neoformations are represented by massive, up to $1.5 \mathrm{~cm}$ thick, carbonate crusts with a cellular texture. The study objects vary in color from light beige to rusty brown. Strong crusts and sinters are developed on both horizontal and vertical surfaces. Stalactites are fragile, hollow tubes with a diameter of 12-15 mm at the base and a length from 20 to $50-55 \mathrm{~mm}$. The wall thickness of these neoformations does not exceed 1-1.5 mm. The external surface of stalactite-like bodies is opaque and rough, sometimes with small inclusions and weakly noticeable zones of thinning. In some cases, the step-like growth pattern is clearly distinguished, as evidenced from the visual diagnostics, even without using special equipment. Neoformations of the upper level of the embankment are represented by thin, white and gray crusts, developed mainly along the joints of the granite slab fence (Figure 1b). Signs of the destruction of the construction can be visually diagnosed at the lower levels of the embankment. In some cases, the facade is completely destroyed, and cement stone in the cracks and voids demonstrates noticeable signs of degradation.

The calcite formations on the facades of the building of the Department of Mineral Resources and Ecology are represented by thin, white crusts developing along engineering joints (Figure 1f). The granite facade is partly destroyed. Neoformations of the facade of the "On Tsarskoi" restaurant building are represented by grayish-white, light-beige crusts, developing along the joints and cracks in the granite tiles poorly attached to the basement surface (Figure 1e). Creamy and white carbonate crusts are widespread within the facades and the front porch of the Tyumen Industrial University Architectural Institute building. The facade of the building is partly destroyed and, in places where there are no granite slabs, it is noticeable that neoformations develop directly on the surface of the cement stone. In these places, the reinforcement is visible on the surface of the destructed concrete (Figure 1a).

\subsection{XRD Analysis}

The main mineral component in all studied carbonate crusts is calcite, while, for stalactite-like formations on the embankment, it is $\mathrm{Mg}$-calcite (Figure 2). In addition, quartz, albite, orthoclase, dolomite, rhodochrosite, and magnetite were found in some of the studied samples. According to the X-ray analysis, the cement stone from the construction joints of the Tura River Embankment contains quartz, K-feldspar, Na-feldspar, kaolinite, hydromica, calcite and siderite. Poorly expressed peaks related to calcite indicate a strong leaching of carbonate material from the cement stone, which is proves the results of visual examinations.

In general, there is a distinct correlation between the composition, morphology, age, color, and ratios of calcite and other mineral components. The most expressed calcite peaks were observed in crusts from the facades of the Tura embankment, where the highest rates of recent mineral formation were noted, and the crusts were deposited from supersaturated solutions. The highest quartz contents were measured in the urban speleothems developed near major highways due to intensive dusting. Some components, such as dolomite, rhodochrosite, quartz, albite, orthoclase and magnetite, are probably related to the inclusions of the cement stone material, while calcite is the only authigenic mineral. This fact was also proved by the results of SEM-EDS analysis. Obviously, these minerals fell into neoformations as clastic material formed during the destruction of the facing materials, as well as during the destruction of concrete slabs and cement. 

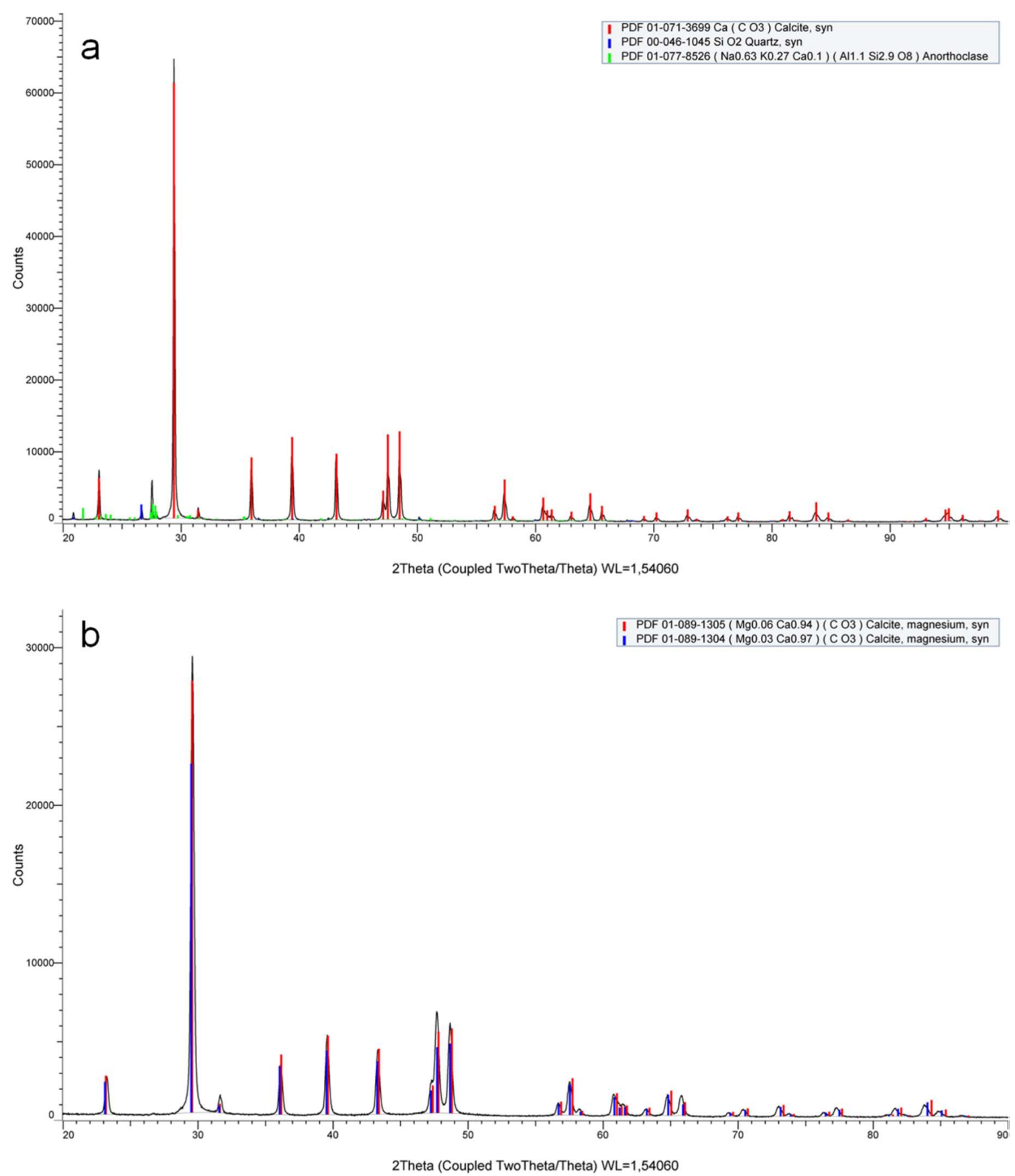

Figure 2. Diffractograms of representative samples of carbonate neoformations: (a) bark on the facades of the second level of the embankment; and (b) stalactite-like formations of the second level of the embankment.

\subsection{Optical Microscopy}

All studied carbonate crusts are characterized by the presence of a clearly defined axial plane, relative to which unidirectional microcrystals of varying configurations develop. The crusts developing on horizontal surfaces are of a denser structure, without voids, and with noticeable traces of secondary recrystallization or at least repeated partial dissolution. The neoformations on vertical surfaces contain many voids that violate the homogeneity of the structure. As a rule, crusts consist of more than 5-6 layers, most of which have a similar thickness. At the same time, increases in both massive and thin layers are noticeable. This indicates irregularity in the growth of urban speleothems and suggests that the crusts are formed during several seasons and perhaps even years under favorable 
conditions [17]. Vertically growing cores have the maximum thickness among all studied samples up to $3.2 \mathrm{~mm}$ and $1.5-2 \mathrm{~mm}$ on average, while horizontally growing crusts are $9-12 \mathrm{~mm}$ thick, with an average thickness of 5-6 $\mathrm{mm}$. The wall thickness of stalactites, on average, does not exceed $2 \mathrm{~mm}$.

Two types of external surface of the crusts can be distinguished. The first type is represented by even and smooth crusts. Calcite crystals on the external sides of these crusts are almost completely smooth and are not visible even under high magnification. As a rule, such surfaces are characteristic of vertically growing crusts. The second type is represented by the crusts, the surface of which has a sharply defined relief and consists of large segregations of microcrystals with a concentrically zoned structure. They develop mainly on horizontal and subhorizontal surfaces under conditions of constant inflow of the supersaturated solutions.

The carbonate crusts on the facades at the lower levels of the embankment have the maximum thickness among all the studied objects. The neoformations represent successive alternations of layers composed of nodules and dendritic intergrowths of microcrystals (Figure 3a,b). When studying the crusts in thin sections, it is noticeable that the primary material for speleothems is heterogeneous. On the general background, there are noticeable signs of partial dissolution and recrystallization. The voids between individual layers are practically absent, and the interlayer space is filled by dendritic aggregates of crystals oriented toward each other and small concentric aggregates.

The crusts developing on the upper levels of the embankment consist of layers that are similar in thickness, which fit closely to each other at the places of junction of granite slabs with the surface (Figure 3c). The voids between the individual layers, comprising these neoformations, are confined to the engineering joints, where the most intense redeposition of the carbonate material occurs. Such voids include both branched dendritic aggregates consisting of elongated crystals with traces of dissolution [29] and aggregates of concentric formations. Such texture can be called colloform, which is typical not only for ore minerals formed from saturated colloid solutions, but also for carbonate speleotherms [30].

When studying the stalactite-like neoformations of the embankment in thin sections, characteristic differences of the external and internal surfaces of the carbonate speleothems were recorded (Figure 3e). The rather homogeneous and smooth external surface consists of intergrown concentric oolith-like microaggregates, zonally colored by alizarin. The internal surface is heterogeneous, representing an alternation of sites filled with small, uniformly distributed, poorly formed calcite crystals and areas with intensive growth of dendritic aggregates consisting of flattened, pointed, tile-like microcrystals. The large dendritic aggregates are oriented from the base to the top. The aggregates that develop from the sidewalls to the center of the inner space are usually composed of smaller but more isolated and better-defined crystals. In some cases, such formations, which develop from the sidewalls, form bridge-like (chord-like) segregations that penetrate the cavity of the stalactite-like bodies. In places where dendritic aggregates grow together, the initial shapes of individual crystals can be distinguished. The evident crystallization centers have not been revealed, which is an indirect sign that growth occurs in the weakening zones of the external layer, where the intensity of crystal growth increases under conditions of an elevated concentration of Ca-rich material.

The walls of stalactite-like bodies have a two-part structure: a thin outer crust with traces of dissolution on the external surface and an inner layer consisting of massive calcite with distinguishable relic outlines of crystals. This structural pattern indicates the repeated process of recrystallization of some parts of the neoformation. Morphologically well-defined dendritic aggregates of crystals are surrounded by almost even surfaces that confirm the simultaneity of the formation of the outer surface and the internal space. In some cases, elongated hollow and concentric aggregates of probably biogenic origin are distinguished (Figure 3f). 

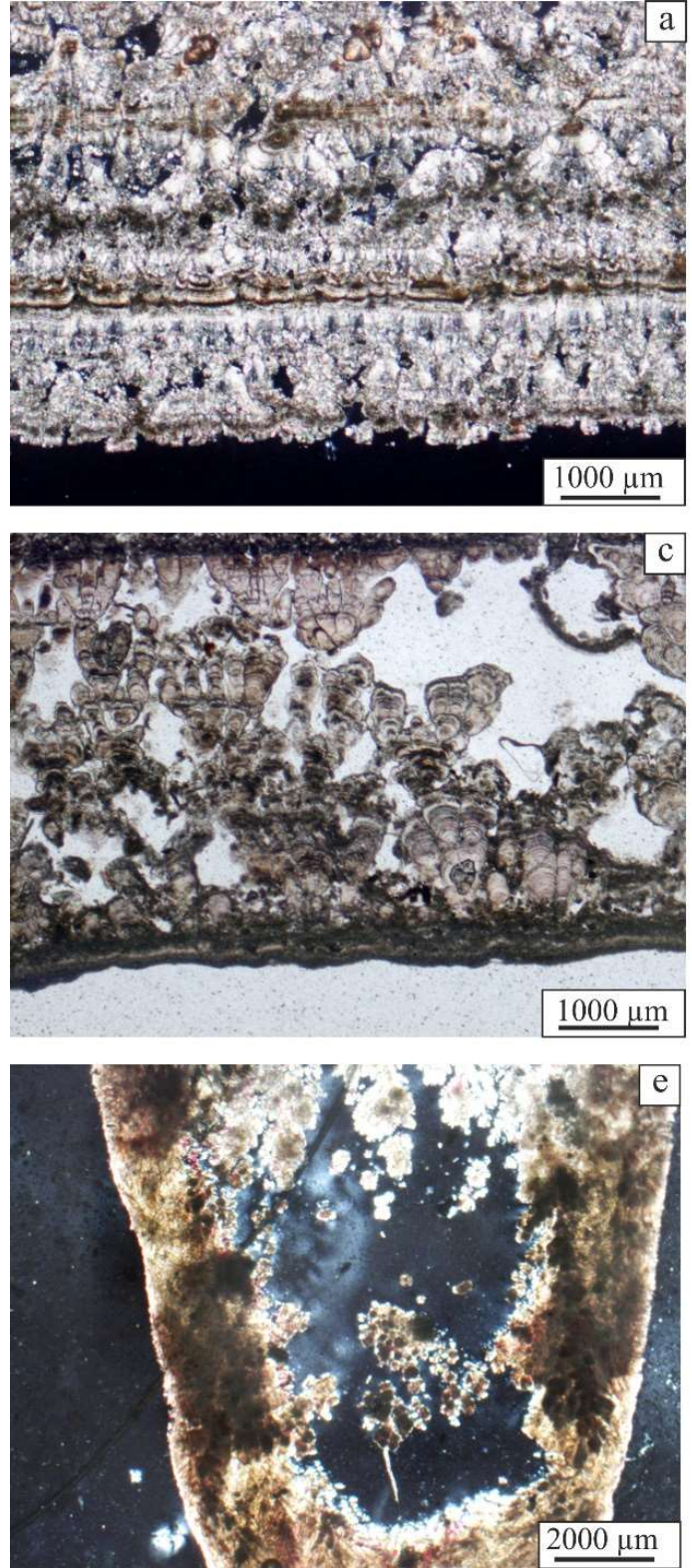
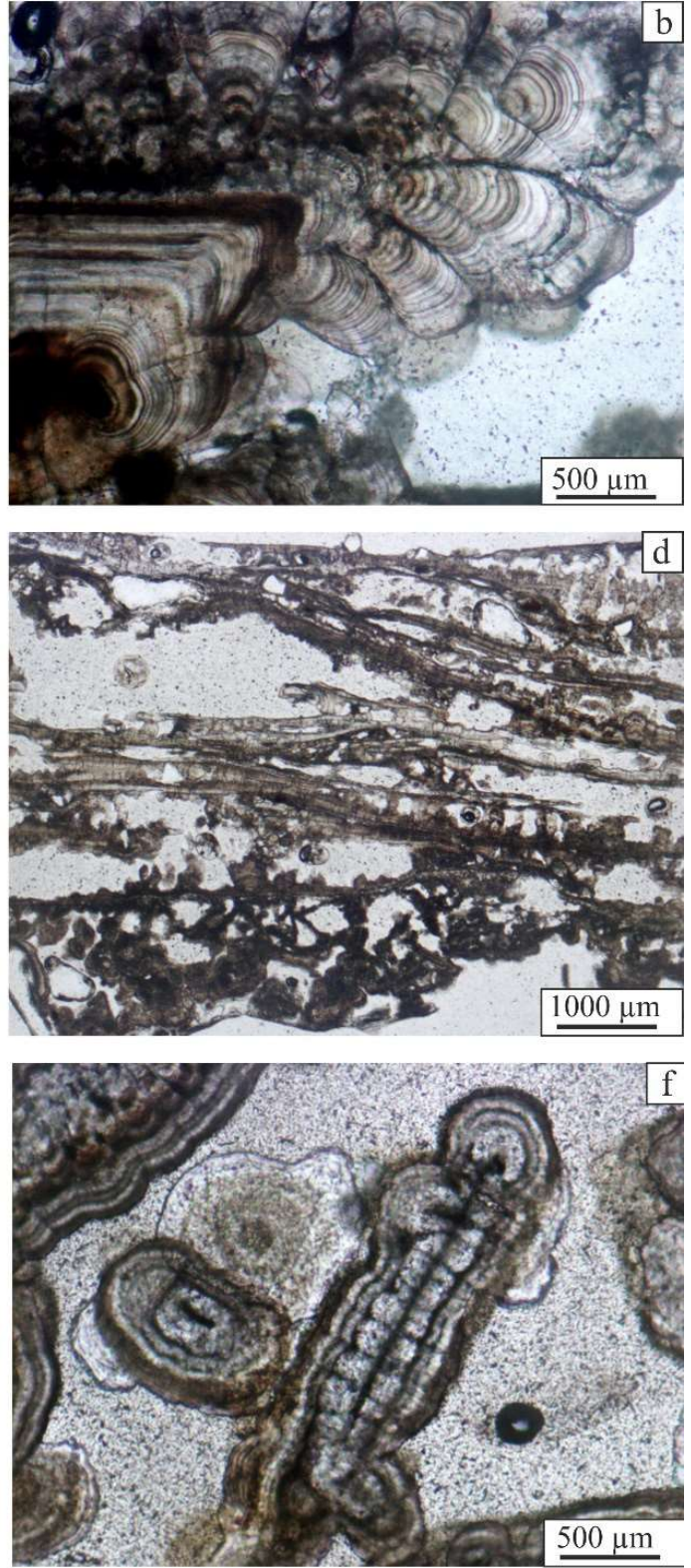

Figure 3. Features of the microstructure of the carbonate neoformations on the facades of buildings and engineering structures of Tyumen: (a) crusts developing on the vertical surfaces of the second level of the Tura embankment (XPL); (b) massive crusts that develop on the horizontal surfaces of the second level of the Tura embankment (PPL); (c) crusts at the upper level embankment of the Tura River (PPL); (d) crusts on the facades of the Department of Mineral Resources and Ecology of the Tyumen Region (PPL); (e) differences in the external and internal surfaces of the stalactite-like neoformations of the second level of the Tura River Embankment (XPL); and (f) aggregates that are likely to develop over the hypha of the fungus and have a biogenic origin (PPL).

The crusts developed on the facades of the building of the Department of Mineral Resources and Ecology of the Tyumen Region have smooth external surfaces. The individual layers that constitute the neoformations are approximately the same thickness and are equally spaced from each other. Two types of crystal formation developing in the interlayer space were recognized. Large rhombohedral crystals that make up sheaf-like aggregates, which are subsequently overgrown by small secondary crystals, represent the first type. Due to this, they are nearly rounded in shape. The second type is represented by small isometric microcrystals that form spherical segregations that are often covered with thin organic films. 
Crusts and sinters on the surfaces of the frontal porch of the "Na Tsarskoi" restaurant have the minimal thickness of all studied objects (Figure 3d). These carbonate crusts consist of many thin layers separated by an abundance of small cavities. It should be noted that cavities filled with microconcretions are observed only near the surface, which indicates low intensity mineral formation processes.

The most heterogeneous crusts, consisting of several layers of unequal thickness have developed on the facades of the Tyumen Industrial University. The surfaces of such neoformations consist of smooth rhombohedral crystals. The internal cavities are filled with microcrystalline aggregates. In addition, there are cracks filled with the carbonate material in the form of massive, almost monolithic blocks with indistinct outlines of flattened columnar crystals.

\subsection{SEM EDS}

SEM observations made it possible to draw the conclusion that separate layers of crusts and stalactite-like bodies consist of elongated, subparallel, columnar aggregates with the concentric structure (Figure $4 a, b$ ). Practically, there is a hole in the center of each of such aggregates, in which the fungal hyphae are often preserved. The latter acts as a structural frame for the development of the internal space of the urban speleothems and determines, in many respects, their morphology and orientation $[18,21]$. Dendrite-like intergrowths of microcrystals originate from the layers consisting of columnar aggregates, which are attached to one of the surfaces (Figure $4 \mathrm{c}, \mathrm{d}$ ). Dendritic aggregates inside the cavities often grow together with oppositely directed ones developed on the adjacent layer. Traces of dissolution are often found on the surfaces of individual crystals. In the process of growth, the cavities are gradually filled with predominantly rhombic crystals and their aggregates, which have close to spherical shapes (Figure 4e,f). It is possible to summarize that the following types of calcite crystals are present in studied neoformations, calcite occurs in the form of split sheen-like, cubic, and spherocrystals, as well as dendritic associations.
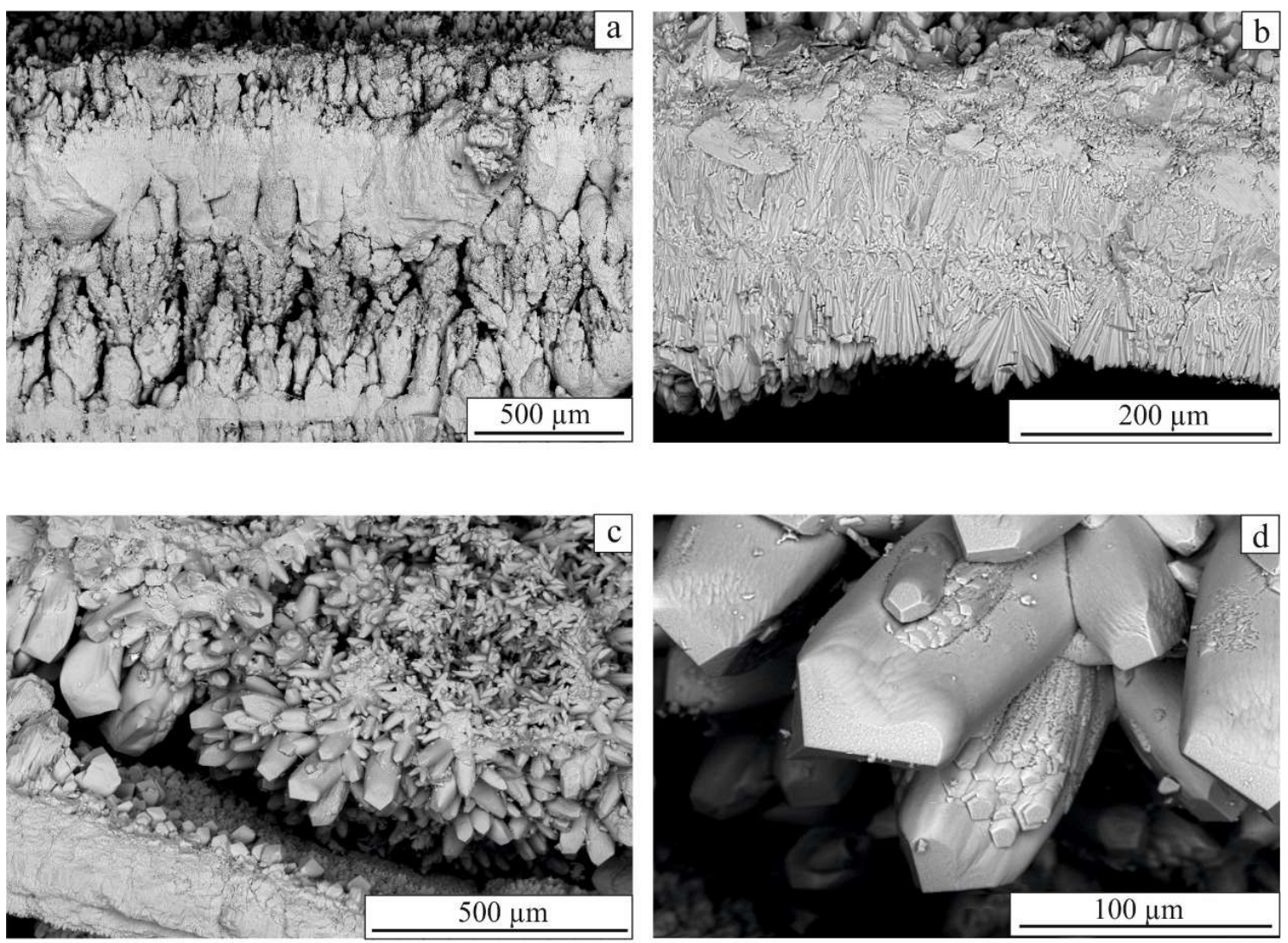

Figure 4. Cont. 

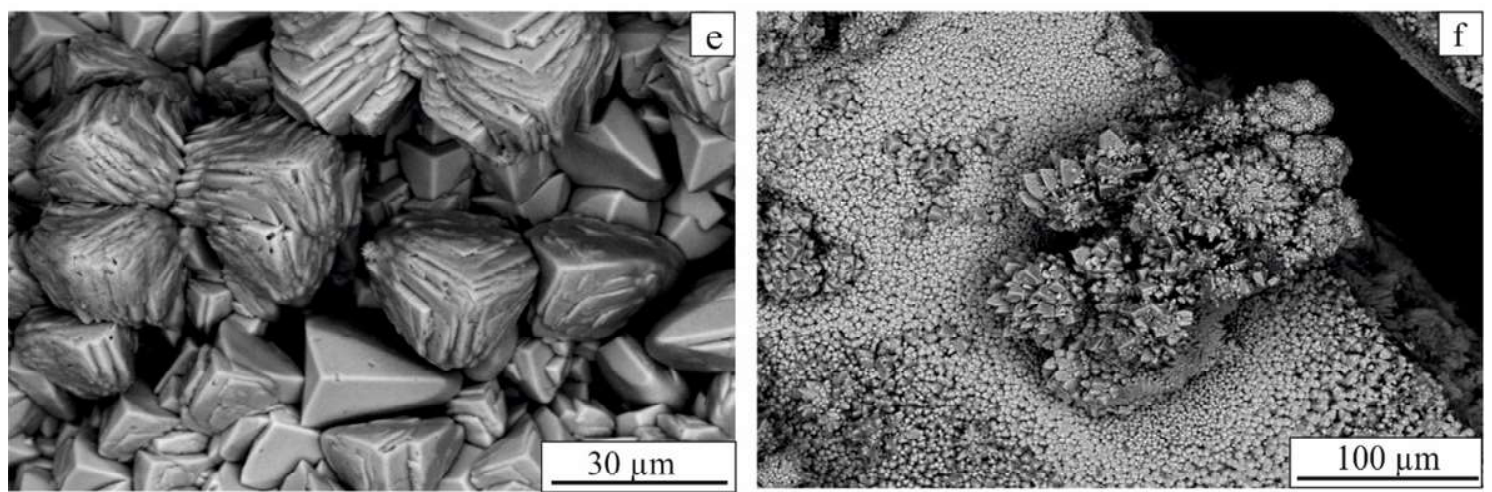

Figure 4. Features of microstructure of carbonate crusts: $(\mathbf{a}, \mathbf{b})$ layers consisting of elongated, subparallel columnar aggregates; $(\mathbf{c}, \mathbf{d})$ dendritic intergrowths of microcrystals; and $(\mathbf{e}, \mathbf{f})$ enlarged fragment of rhombohedral crystals with split faces.

Sometimes, the internal structure of carbonate crusts is limited by the boundaries at which crystal growth is abruptly interrupted, being replaced by the subsequent formation of a new structure. In single cases, noticeable interlayers enriched in organic matter and various inclusions are confined to these boundaries. However, in most cases, there are no evident reasons for the interruption of the crystallization process. Accordingly, it is possible to suggest that the mechanical cleaning of the facades is the most obvious reason for the formation of such boundaries.

SEM-EDS analysis revealed that $\mathrm{Ca}$ is the predominate component of all studied samples and their morphological elements. Mg-containing spectra (usually in combination with $\mathrm{Si}$ and $\mathrm{Al}$ signals, which most resemble chlorite) were observed only in the detrital component of the neoformation (Figure 5).

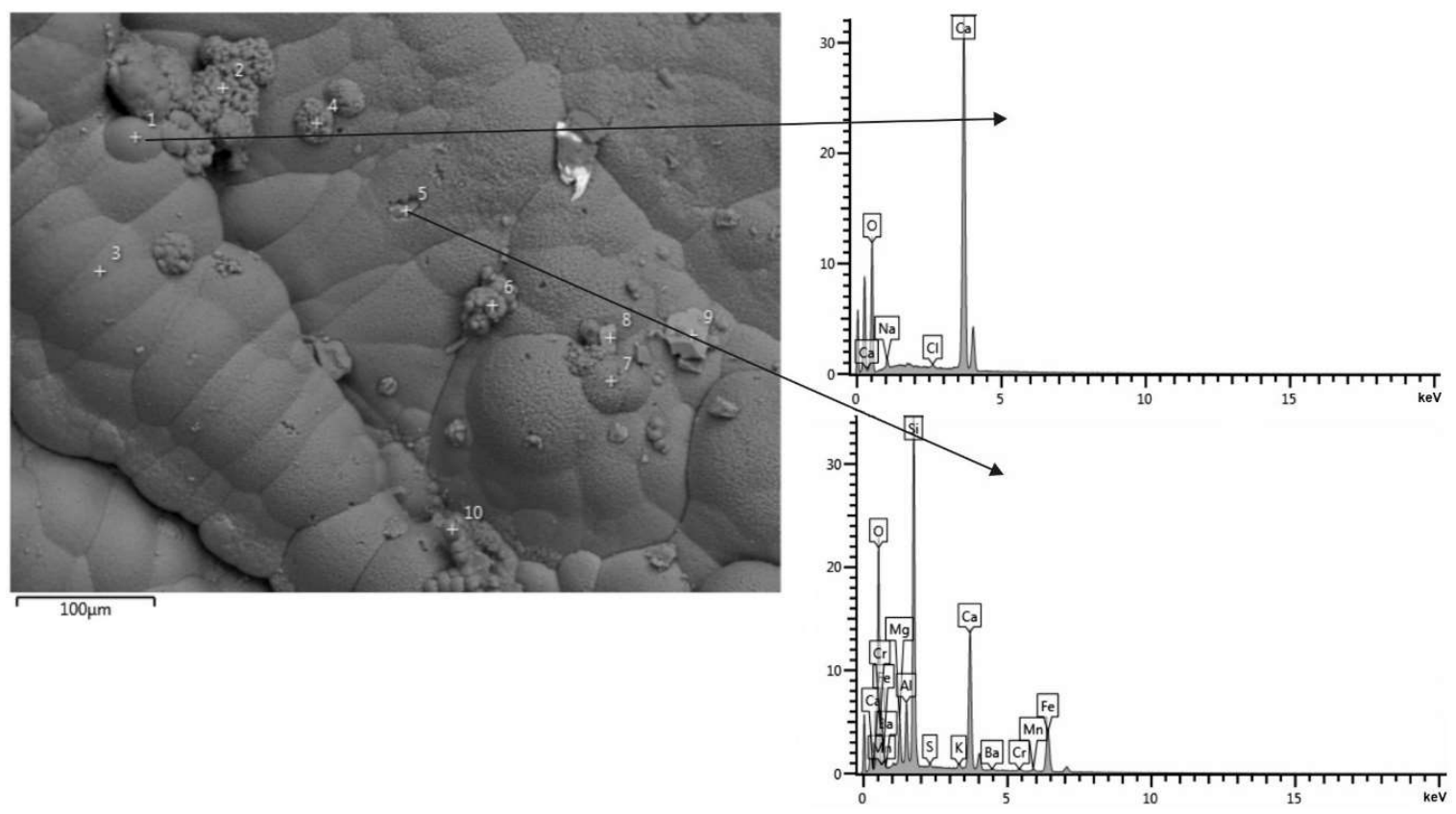

Figure 5. EDS-spectra representing main morphological elements of studied neoformations and particles (inclusions) of detrital origin.

Precipitation of $\mathrm{NaCl}$ crystals was observed for the carbonate crusts formed at the level of the roadway (Figure 6). The salt microcrystals constitute interlayers inside the dendrite-like aggregates, which fix the periods of active use of reagents on adjacent streets. Impurities in the form of dust particles, the crumbling building material, and silicate microspheres were found in almost all samples. 

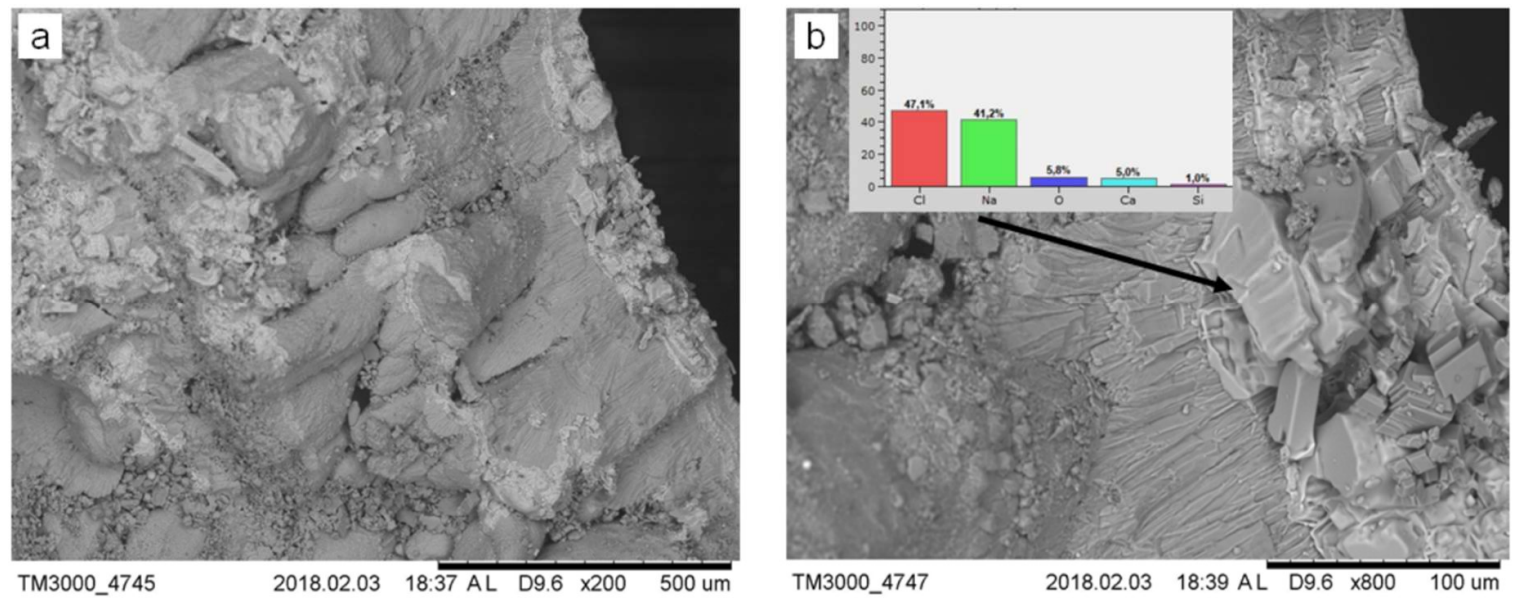

Figure 6. Salt precipitations on the surface of crust developing at the upper level of the embankment: (a) general view; and (b) EDS spectra.

The mycelium of fungi (presumably from the Penicillium group), represented by filamentous, often hollow hyphae with rare extensions (nodules), was found in all of the studied samples as well as in samples of the cement stone. The hyphae of fungi are covered by carbonate material to varying degrees and form subparallel planes that make up the main "body" of crusts and stalactites (Figure 7) [31,32]. Most of the hyphal tubes are completely bonded by calcite, while the organic matter of the hyphae is not mineralized. This may be due to there being insufficient time for mineralization, because living organisms were still alive at the time of sampling. Such tube aggregates have concentric structures on their cross sections. With distance from the hyphal body, each new layer is composed of larger crystallites that are radially directed from the center to the periphery.

Apart from the mycelium, remains of bacterial colonies, which are often reported as an important factor of speleothem development in caves [33], were found in all studied samples. In general, the typical structure of carbonate crusts formed at the engineering constructions and buildings represents an alternation of interlayers consisting of tubular aggregates formed by the fungal hyphae and interlayers consisting of concentric spherical aggregates resulting from the activity of microbial communities (Figure 8a,b). Some bacterial colonies (probably symbiotic) are confined to the hyphae and can be found in the form of spherical aggregates developing along carbonate tubes in almost all samples. At the same time, there are reasonably thick interlayers that almost entirely consist of such aggregates with concentric structures that have cavities in the center and holes on the surface. In some cases, organic films, formed as a result of the development of bacterial colonies, are preserved. These films outline the surfaces of carbonate spheres (Figure $8 c, d$ ) and are probably the relics of cysts, which were formed by bacterial colonies in order to survive under unfavorable conditions. It should be noted that crusts with interlayers formed by carbonatized bacterial formations are the densest among all studied samples. 

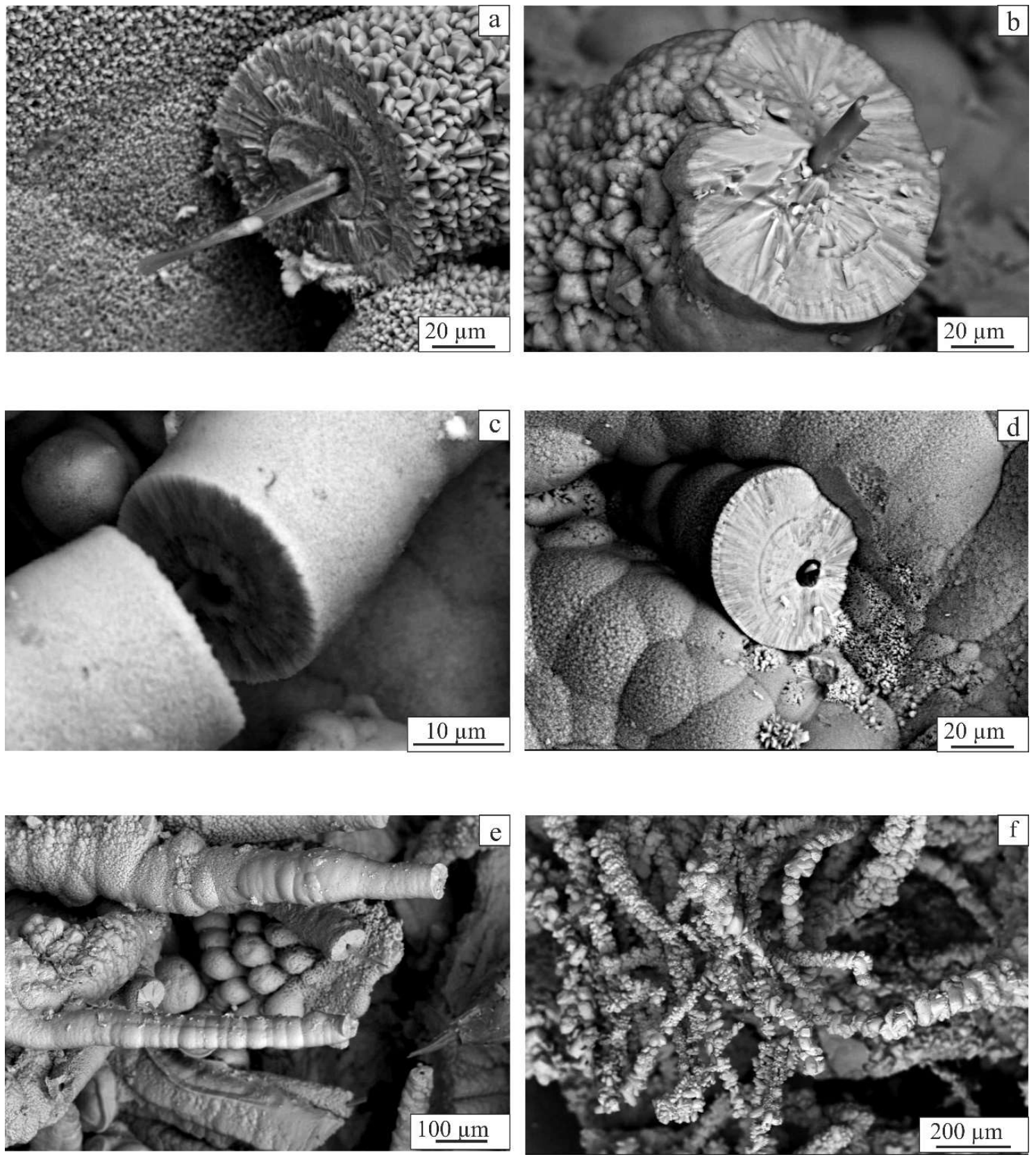

Figure 7. Mineralized tubular aggregates: (a-d) with preserved fungal hyphae in the central part; and $(\mathbf{e}, \mathbf{f})$ diversity of calcite tubular aggregates morphology.

In addition to direct evidence of prokaryotic-eukaryotic carbonate mineralization, there are also several indirect signs. One of these signs is the presence of split sheaf-like intergrowths of calcite crystals found in several samples. Crystals with a characteristic morphology were noted by several researchers when studying the processes of the calcite mineralization by carbonate-reducing bacteria [19]. 

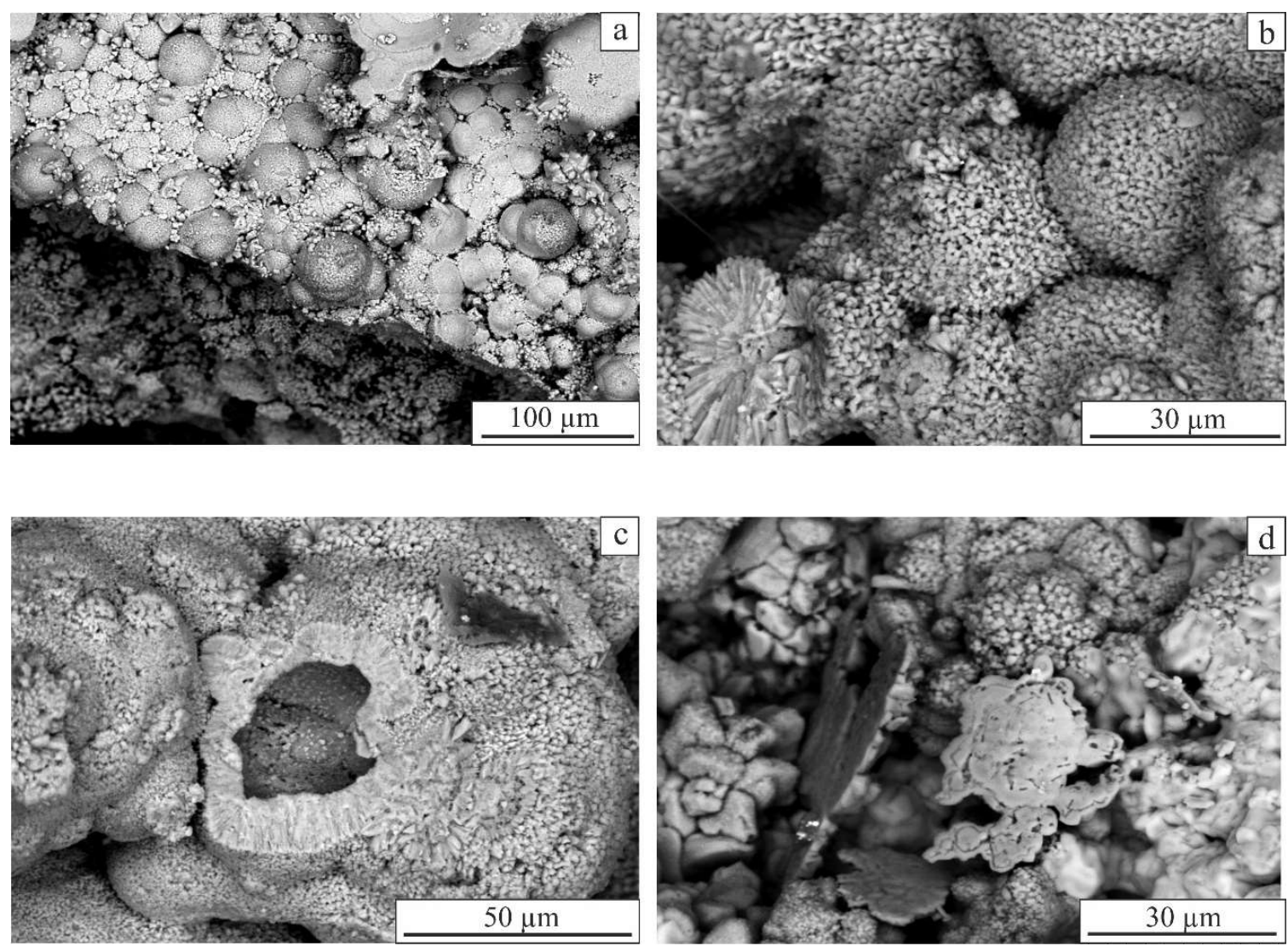

Figure 8. Signs of possible bacterial mineralization of calcite: $(\mathbf{a}, \mathbf{b})$ spherical aggregates; and (c,d) relicts of bacterial films.

\subsection{Confocal Laser Microscopy}

The results of studying carbonate crust and stalactites using confocal laser microscopy show the presence of uneven fluorescent zones between individual thick layers of urban speleothems and within individual dendritic aggregates, manifested in the form of concentric fluorescence bands (Figure 9). As in cave stalactites, several calcite generations with different fluorescence properties-dark non-fluorescent calcite and light fluorescent calcite-were distinguished. A similar sequence of layers is characteristic of cave speleothems [28,34]. It is probable that the observed fluorescence bands record the seasonal variability in the content and composition of organic acids in water filtered through engineering structures [35] as well as the different intensities of biomineralization processes associated with alternating drying and moistening periods, as well as changes in the temperature regime. In contrast to natural speleothems, which show a more stable linear growth pattern, interlayers with varying fluorescence in the objects under consideration reflect both seasonal and intraseasonal variations in conditions during the period of their development. 

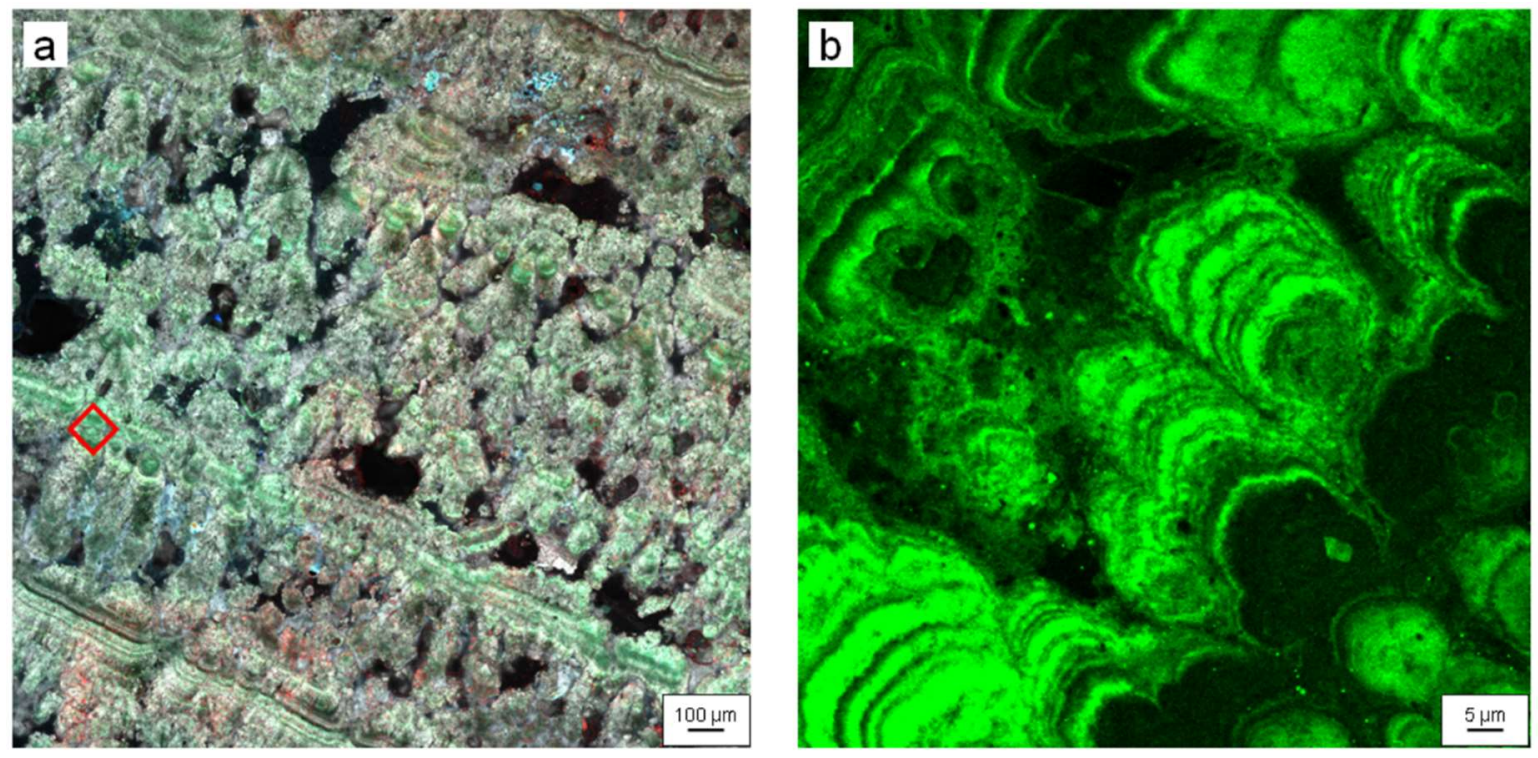

Figure 9. Visualization of confocal laser microscopy: (a) differences in the fluorescence of individual layers of carbonate crusts; and (b) alternating dark non-fluorescent and light fluorescent calcite generations within individual aggregates.

\section{Discussion}

The results of our study suggest that the formation of carbonate crusts, sinters and stalactites is a stadial process. During the first stage, a thin calcite crust grows in zones adjacent to construction joints. At a later stage, the carbonate crusts gradually increase their thickness and area, while the repeated processes of recrystallization and compaction lead to a significant increase in their strength. Later, the concentrically zoned formations begin to develop on steep parts of the constructions with uneven surfaces. These formations become the basis for the development of stalactite-like bodies, if the redeposition of carbonate material is intensive. During the growth of studied speleothems, the rings gradually decrease in diameter.

Based on the observations and microscopic studies, it is possible to make the conclusion that the main body and the internal microrelief of the studied neoformations develop simultaneously. The microrelief is formed by dendritic aggregates in zones of elevated inflow of the supersaturated solutions, which corresponds to weakened areas on the external surface. The carbonate crusts are perennial formations, while stalactite-like bodies are quasi-seasonal. As usual, most of the stalactites break under certain weather conditions (summer drought, extreme wind, storm rainfall).

The formation of carbonate crusts is a complex and multistage process, which is subject to seasonal fluctuations and involves both chemogenic and biogenic pathways of mineral formation. Without taking into account the activity of microorganisms, this process can be generally described by the chemical reaction $\mathrm{CaCO}_{3}+\mathrm{H}_{2} \mathrm{O}+\mathrm{CO}_{2}<=>\mathrm{Ca}^{2+}+2 \mathrm{HCO}_{3}{ }^{-}$. At the first stage, rainwater, straining through the entire volume of engineering constructions, causes the dissolution of calcite contained in the cement stone with the formation of $\mathrm{Ca}^{2+}$ and $\mathrm{HCO}_{3}{ }^{-}$. The reaction is reversible, in particular when the $\mathrm{CO}_{2}$ concentration changes relative to its equilibrium concentration, which leads to the formation of carbonate crusts and sinters [19].

The processes of calcite biomineralization are much more complex, since they are related to the special features of fungi metabolism and the mechanisms of their adaptation to the existence in high-alkaline environment [36-38]. The fungi from Penicillium group secrete various organic acids, including oxalic acid that shifts the $\mathrm{pH}$ of the medium to the acidic values and inhibits the crystallization of calcite and promote the crystallization of oxalates [39-41]. Electron microscopy showed that precipitation of $\mathrm{CaCO}_{3}$ by fungi has two ways: spherocrystals with a fibrous structure and hyphal mineralization (biomorphosis). 
The obtained results confirm the suggestion of some authors [19,32,42-44] that living organisms (fungi and bacterial colonies) play a significant role in the formation of speleothems. It is likely that the prokaryotic-eukaryotic communities play the main role in the precipitation of carbonates in urban speleothems at the initial stages of their development and determine their growth rate. Since the ecosystem is open to climatic and anthropogenic impacts, partial mechanical destruction and chemical dissolution, which affect the chemogenic redeposition of calcite, also play a certain role. Chemogenic crystallization of calcite (and partial dissolution) takes place in the voids remaining after fossilization of the sheaths of fungi and bacteria.

The role of biogenic sedimentation of carbonate material is also indirectly manifested in the morphology and diversity of crystal forms. Crystals with characteristic morphology were obtained by several researchers while studying the in vitro formation of calcite by carbonate precipitating bacteria taken from the Shulgan-Tash cave. It has been established that vital activity of bacterial communities and separately cultivated isolates (strains) changes the $\mathrm{pH}$ of the medium to 8.5, which leads to precipitation of calcite crystals. The dominant forms obtained in the experiments with isolates were split crystals [45]. In addition, it is important to note another possible way of carbonate formation that takes place after the death of microorganisms-incrustation or biomorphosis of parts of organisms capable for mineralization. For some fungi from the genus Penicillium sp. and P. implicatum the deposition of calcite with specific microfiber habitus and hyphae fossilization was observed after the death of the colonies. However, bacterial microfossils with mineralized membranes are rather rare.

There are several important features associated with the formation of carbonate crusts on the facades of buildings. Firstly, the studied neoformations were found mainly on the facades of buildings and constructions located in the near-valley part of Tyumen city under conditions of elevated humidity. It should be emphasized that carbonate crusts have developed on the facades of both recent buildings (less than five years) and those that were constructed more than 15-20 years ago. Consequently, the age of constructions cannot be considered as a factor that determines the possibility of their formation, as noted in some works [18]. The most intensive development of massive crusts with a characteristic cellular structure was recorded for the facades of the river embankment, where direct signs of its degradation were rather limited. The studies of the cement stone from this location revealed the significant leaching of carbonate cement, which is the main source of material for intensive development of speleotherms. At the same time, this process is less intensive on the facades of older, partly destroyed buildings, where a significant amount of carbonate material in the cement is leached.

It is not possible to establish an unambiguous relationship between the intensity of urban speleothem growth and the conditions of specific engineering structures (locality, features of temperature and water conditions), since all structures under consideration differ in terms of construction, volume, and the type of cement used. At the same time, it should be noted that dense neoformations develop in over-moistened areas (lower levels of the embankment), indicating abundant signs of biogenic mineral formation. Thinner carbonate crusts and sinters are formed on the open, well sun-heated, and windblown south facades, largely due to the chemogenic precipitation of carbonates. Therefore, it is possible to suggest that the main factors that promote the development of neoformations are the structural defects of the buildings as well as the breach of operating procedures during the construction activities. Living organisms and the conditions of the buildings only determine the intensity of carbonate leaching and redeposition.

The results of our study show that the mechanical cleaning of facades is not an adequate method to prevent carbonate formation, as the growth rate of almost all crusts and sinters is quite high [7]. In addition, the development of urban speleothems is intensified by the influence of living organisms, namely fungi and bacteria. Therefore, measures for the prevention of this process, such as joint sealing and antimicrobial surface treatment, should be much more promising than temporary cleaning.

\section{Conclusions}

(1) Carbonate crusts, developed on the facades of different buildings and constructions in the city of Tyumen, vary widely in terms of structure, thickness, and mineral composition. The variations 
are stipulated by the intensity of leaching of the carbonate material as well as the age and design features of specific constructions.

(2) Calcite and, in some cases, $\mathrm{Mg}$-calcite are the main mineral components of the studied urban speleothems. In addition, they include quartz, albite, orthoclase, dolomite, rhodochrosite, and magnetite (in individual samples). All minerals except for calcite, which generally forms on all structural elements of neoformations, are related to inclusions of cement stone ore other building materials that appear in speleotherms as a result dusting and destruction of the facades.

(3) The obtained results confirm the previous suggestions about the significant roles of living organisms, such as fungi and bacterial colonies, in the formation of urban speleotherms. It appears that the biogenic processes prevail at the early development stages of carbonate neoformations and are responsible for the rate of their growth. Gradual intensification of the processes of chemogenic crystallization of calcite occurs mainly after the formation of the main volume of carbonate crusts. A key role of the biogenic precipitation of the carbonate material is also evident in the morphology and variety of crystal shapes.

(4) The study results indicate a high rate of formation of carbonate crusts and its dependence on seasonal cycles and intra-seasonal fluctuations in temperature and precipitation.

(5) The significant role of the biogenic processes in the intensification of carbonate precipitation is an additional argument in favor of the poor effectiveness of mechanical cleaning of facades, as it is oriented only on the consequences but not the cause. Such mechanism of their development has to be taken into account when planning the measures for their removal and prevention of similar processes for objects under construction. Therefore, precautions against the development of such processes, such as joint sealing and antibacterial surface treatment, could be rather more promising.

Author Contributions: A.N. and A.K. performed the fieldwork and sampling, conceived and designed the experiments and wrote the paper. L.L., B.S. and S.M. performed mineralogical analysis, participated in microscopic studies, and discussed the obtained data.

Funding: This research received no external funding.

Acknowledgments: The authors are sincerely grateful to D.V. Voroshchuk and E. O'Connor for assistance in preparing the manuscript in English. We would like to thank the two anonymous reviewers for their constructive comments that improved the manuscript.

Conflicts of Interest: The authors declare no conflict of interest.

\section{References}

1. Amoroso, G.G.; Fassina, V. Stone Decay and Conservation: Atmospheric Pollution Cleaning Consolidation and Protection; Elsevier: Amsterdam, The Netherlands; New York, NY, USA, 1983.

2. Christaras, B. Durability of building stones and weathering of antiquities in Creta/Greece. Bull. Int. Assoc. Engin. Geol. 1991, 44, 17-25. [CrossRef]

3. Perez-Monserrat, E.M.; de Buergo, M.A.; Gomez-Heras, M.; Muriel, M.J.V.; Gonzalez, R.F. An urban geomonumental route focusing on the petrological and decay features of traditional building stones used in Madrid Spain. Environ. Earth Sci. 2013, 69, 1071-1084. [CrossRef]

4. Tittarelli, F.; Moriconi, G.; Bonazza, A. Atmospheric deterioration of cement plaster in a building exposed to urban environment. J. Cult. Herit. 2008, 9, 203-206. [CrossRef]

5. Sabbioni, C.; Zappia, G.; Riontino, C.; Blanco-Varela, M.T.; Aguilera, J.; Puertas, F.; Van Balen, K.; Toumbakari, E.E. Atmospheric deterioration of ancient and modern hydraulic mortars. Atmos. Environ. 2001, 35, 539-548. [CrossRef]

6. Török, Á. Surface strength and mineralogy of weathering crusts on limestone buildings in Budapest. Build. Environ. 2003, 38, 1185-1192. [CrossRef]

7. Novoselov, A.A. Singer carbonate technogenic mineral formations of the Tyra river embankment: Development conditions, structure features and indication potential. Bull. Tomsk Polytech. Univ. Geo Asset. Eng. 2017, 328, $46-54$. 
8. Novoselov, A.A.; Konstantinov, A.O. Carbonate technogenic mineral formations on the facades of buildings of Tyumen: Development conditions and diversity. Bull. Tomsk Polytech. Univ. Geo Asset. Eng. 2019, 330, in press.

9. Alves, C. “White” crusts on recent buildings. Mater. Sci. Forum 2010, 636-637, 1300-1305. [CrossRef]

10. Dow, C.; Glasser, F.P. Calcium carbonate efflorescence on Portland cement and building materials. Cem. Concr. Res. 2003, 33, 147-154. [CrossRef]

11. Flores-Colen, I.; de Brito, J.; de Freitas, V.P. Stains in facades' rendering-Diagnosis and maintenance techniques' classification. Constr. Build. Mater. 2008, 22, 211-221. [CrossRef]

12. Moropoulou, A.; Tsiourva, T.; Bisbikou, K.; Tsantila, V.; Biscontin, G.; Longega, G.; Groggia, M.; Dalaklis, E.; Petritaki, A. Evaluation of cleaning procedures on the facades of the Bank of Greece historical building in the center of Athens. Build. Environ. 2002, 37, 753-760. [CrossRef]

13. Vereshchagin, O.S.; Frank-Kamenetskaya, O.V.; Shumilova, K.V.; Khadeeva, N.Y. Carbonate sediments on decorative fountains in Peterhof, Russia. Environ. Earth Sci. 2018, 77, 56. [CrossRef]

14. González-Gómez, W.S.; Quintana, P.; Gómez-Cornelio, S.; García-Solis, C.; Sierra-Fernandez, A.; Ortega-Morales, O.; De la Rosa-García, S.C. Calcium oxalates in biofilms on limestone walls of Maya buildings in Chichén Itzá, Mexico. Environ. Earth Sci. 2018, 77, 230. [CrossRef]

15. Auras, M.; Beer, S.; Bundschuh, P.; Eichhorn, J.; Mach, M.; Scheuvens, D.; Schorling, M.; von Schumann, J.; Snethlage, R.; Weinbruch, S. Traffic-related immissions and their impact on historic buildings: Implications from a pilot study at two German cities. Environ. Earth Sci. 2013, 69, 1135-1147. [CrossRef]

16. Graue, B.; Siegesmund, S.; Oyhantcabal, P.; Naumann, R.; Licha, T.; Simon, K. The effect of air pollution on stone decay: The decay of the Drachenfels trachyte in industrial, urban, and rural environments-A case study of the Cologne, Altenberg and Xanten cathedrals. Environ. Earth Sci. 2013, 69, 1095-1124. [CrossRef]

17. Kazdym, A.A. Natural and man-made formation of calcite-Sinters and shelfstones: Genesis, morphology, microstructure. Mineral. Tekhnogeneza 2007, 8, 269-287.

18. Potapov, S.S.; Parshina, N.V.; Maximovich, N.G.; Naumov, V.A. The technogenic speleothems. Mineral. Tekhnogeneza 2005, 6, 12-22.

19. Leonova, L.V.; Potapov, S.S.; Kuz'mina, L.Y.; Cherviatsova, O.Y.; Glavatskikh, S.P.; Riabova, A.S. The technogenic sediments of biocarbonates and their experimental formation. Mineral. Tekhnogeneza 2014, 15, 113-129.

20. Erokhin, Y.V.; Khiller, V.V. Man-made calcite on the fortifications of the island Dyurëya (Troms, Northern Norway). Mineral. Tekhnogeneza 2016, 17, 173-177.

21. Kazdym, A.A.; Chigova, A.A.; Astachov, M.I. New man-caused carbonate formations on the concrete surfaces of the Nerl-river bridge. Mineral. Tekhnogeneza 2005, 6, 32-39.

22. Liu, Z.; He, D. Special speleothems in cement-grouting tunnels and their implications of the atmospheric $\mathrm{CO}_{2}$ sink. Environ. Geol. 1998, 35, 258-262. [CrossRef]

23. Maksimovich, G.A. Carbonate stalactites and stalagmites in the basement of the Moscow State University. Peshchery 1976, 16, 24-35.

24. Pons-Branchu, E.; Ayrault, S.; Roy-Barman, M.; Bordier, L.; Borst, W.; Branchu, P.; Douville, E.; Dumont, E. Three centuries of heavy metal pollution in Paris (France) recorded by urban speleothems. Sci. Total Environ. 2015, 518-519, 86-96. [CrossRef] [PubMed]

25. Climate of Tyumen. Available online: http://www.pogodaiklimat.ru/climate/28367.htm (accessed on 9 January 2019).

26. Guseinov, A.N. Ecology of Tyumen: State, Problems; Slovo Publ: Tyumen, Russia, 2001.

27. Cox, G.C.; Salih, A.; James, J.M.; Allaway, W.G. Confocal microscopy of cyanobacteria in calcite speleothems. Zool. Stud. 1995, 34, 5-6.

28. Orland, I.J.; Bar-Matthews, M.; Kita, N.T.; Ayalon, A.; Matthews, A.; Valley, J.W. Climate deterioration in the eastern Mediterranean as revealed by ion microprobe analysis of a speleothem that grew from 2.2 to $0.9 \mathrm{ka}$ in Soreq Cave Israel. Quat. Res. 2009, 71, 27-35. [CrossRef]

29. Kendall, A.C.; Broughton, P.L. Origin of fabrics in speleothems composed of columnar calcite crystals. J. Sediment Petrol. 1978, 48, 519-538. [CrossRef]

30. Field, L.P.; Milodowski, A.E.; Shaw, R.P.; Stevens, L.A.; Hall, M.R.; Kilpatrick, A.; Gunn, J.; Kemp, S.J.; Ellis, M.A. Unusual morphologies and the occurrence of pseudomorphs after ikaite $\left(\mathrm{CaCO}_{3} \bullet 6 \mathrm{H}_{2} \mathrm{O}\right)$ in fast growing, hyperalkaline speleothem. Mineral. Mag. 2017, 81, 565-589. [CrossRef] 
31. Baskar, S.; Routh, J.; Baskar, R.; Kumar, A.; Miettinen, H.; Itävaara, M. Evidences for microbial precipitation of calcite in speleothems from Krem Syndai in Jaintia Hills Meghalaya India. Geomicrobiol. J. 2016, 10, 906-933. [CrossRef]

32. Verrecchia, E.P.; Dumont, J.L.; Karin, E. Role of calcium oxalate biomineralization by fungi in the formation of calcretes; A case study from Nazareth, Israel. J. Sediment Res. 1993, 63, 1000-1006. [CrossRef]

33. Pacton, M.; Breitenbach, S.F.M.; Lechleitner, F.A.; Vaks, A.; Rollion-Bard, C.; Gutareva, O.S.; Osintcev, A.V.; Vasconcelos, C. The role of microorganisms in the formation of a stalactite in Botovskaya Cave, Siberia-Paleoenvironmental implications. Biogeosciences 2013, 10, 6115-6130. [CrossRef]

34. Orland, I.J.; Bar-Matthews, M.; Ayalon, A.; Matthews, A.; Kozdon, R.; Ushikubo, T.; Valley, J.W. Seasonal resolution of Eastern Mediterranean climate change since 34 ka from a Soreq Cave speleothem. Geochim. Cosmochim. Acta 2012, 89, 240-255. [CrossRef]

35. Tan, M.; Baker, A.; Genty, D.; Smith, C.; Esper, J.; Cai, B. Applications of stalagmite laminae to paleoclimate reconstructions: Comparison with dendrochronology/climatology. Quat. Sci. Rev. 2006, 25, 2103-2117. [CrossRef]

36. Burford, E.P.; Hillier, S.; Gadd, G.M. Biomineralization of fungal hyphae with calcite $\left(\mathrm{CaCO}_{3}\right)$ and calcium oxalate mono- and dihydrate in carboniferous limestone microcosms. Geomicrobiol. J. 2006, 23, 599-611. [CrossRef]

37. Bindschedler, S.; Millière, L.; Cailleau, G.; Job, D.; Verrecchia, E.P. Calcitic nanofibres in soils and caves: A putative fungal contribution to carbonatogenesis. Lond. Geol. Soc. Spec. Publ. 2010, 336, 225-238. [CrossRef]

38. Bindschedler, S.; Cailleau, G.; Verrecchia, E. Role of fungi in the biomineralization of calcite. Minerals 2016, 6, 41. [CrossRef]

39. Luo, J.; Chen, X.; Crump, J.; Zhou, H.; Davies, D.G.; Zhou, G.; Zhang, N.; Jin, C. Interactions of fungi with concrete: Significant importance for bio-based self-healing concrete. Constr. Build. Mater. 2018, 164, 275-285. [CrossRef]

40. Unković, N.; Erić, S.; Šarić, K.; Stupar, M.; Savković, Ž.; Stanković, S.; Stanojević, O.; Dimkić, I.; Vukojević, J.; Grbić, M.L. Biogenesis of secondary mycogenic minerals related to wall paintings deterioration process. Micron 2017, 100, 1-9. [CrossRef]

41. Sazanova, K.V.; Shchiparev, S.M.; Vlasov, D.Y. Formation of Organic Acids by Fungi Isolated from the Surface of Stone Monuments. Microbiology 2014, 83, 516-522. [CrossRef]

42. Forti, P. Biogenic speleothems: An overview. Int. J. Speleol. 2001, 30, 39-56. [CrossRef]

43. Cailleau, G.; Verrecchia, E.P.; Braissant, O.; Emmanuel, L. The biogenic origin of needle fibre calcite. Sedimentology 2009, 56, 1858-1875. [CrossRef]

44. Jones, B. Microbes in caves: Agents of calcite corrosion and precipitation. Lond. Geol. Soc. Spec. Publ. 2010, 336, 7-30. [CrossRef]

45. Leonova, L.V.; Kuzmina, L.Y.; Ryabova, A.S.; Simakova, Y.S.; Glavatskikh, S.P.; Cherviatsova, O.Y. Bacterially-mediated carbonate formation at the laboratory environment. Mineral. Tekhnogeneza 2015, 16, 139-147.

(C) 2019 by the authors. Licensee MDPI, Basel, Switzerland. This article is an open access article distributed under the terms and conditions of the Creative Commons Attribution (CC BY) license (http://creativecommons.org/licenses/by/4.0/). 